\title{
UPAYA PENAGGULANGAN GELANDANGAN DAN PENGEMIS DI KECAMATAN MARTAPURA KOTA KABUPATEN BANJAR (Perda Kabupaten Banjar Nomor 2 Tahun 2014 Tentang Penanggulangan Gelandangan dan Pengemis)
}

\author{
Tamliha Harun \\ FIA, Universitas Achmad Yani Banjarmasin \\ Email: tamlihaharun@yahoo.co.id
}

\begin{abstract}
This research was conducted with the aim to find out more about the efforts made by the Banjar Regency Government in tackling the problem of homelessness and beggars in Martapura Kota District, Banjar Regency. It is expected that the results of this study can provide input for the Banjar Regency Government in an effort to maximize the sprawl response in the region. This research is a descriptive study, with data collection techniques: interviews, observation, and documentation, then the results are analyzed qualitatively. The results of this study indicate that: a. Sprawl in Banjar District (especially in Martapura Kota District) has been carried out through preventive efforts, repressive measures, and rehabilitation (rehabilitative) efforts based on Regional Regulation Number 2 of 2014 concerning Countermeasures for Homelessness and Beggars; $b$. These sprawl countermeasures are still not optimal, if referred to the regional regulation which covers them, especially rehabilitation efforts have not been carried out properly; $c$. The efforts of the sprawl control have not yet been maximized due to several obstacles, including the lack of apparatus (Social Service and Satpol PP), the lack of available budget allocations, and the unavailability of flat construction facilities and infrastructure as needed; $d$. Criminal sanctions and non-criminal sanctions in accordance with the Regional Regulation, cannot yet be applied firmly and consistently to sprites who have committed violations, as a result sanctions imposed on sprawl do not cause a deterrent effect.
\end{abstract}

Keywords: homelessness, beggars, banjar regency

\section{PENDAHULUAN}

Tujuan Negara Republik Indonesia tercantum dalam Pembukaan UUD 1945 alenia keempat, yaitu melindungi segenap bangsa Indonesia dan seluruh tumpah darah Indonesia dan untuk memajukan kesejahteraan umum, mencerdaskan kehidupan bangsa, dan ikut melaksanakan ketertiban dunia yang berdasarkan perdamaian abadi dan keadilan sosial. Itu artinya negara kita mempunyai kewajiban ke dalam dan ke luar. Kewajiban ke dalam adalah melindungi seluruh rakyat Indonesia baik yang berada di dalam maupun di luar negeri, memajukan kesejahteraan rakyat dan mencerdasan kehidupan bangsa. Sedangkan kewajiban ke luar adalah ikut terlibat menjaga ketertiban dan perdamaian negara-negara di dunia.

Untuk mewujudkan tujuan negara tersebut, terutama melindungi segenap tumpah darah Indonesia, memajukan kesejahteraan umum dan mencerdaskan kehidupan bangsa dilakukanlah upaya pembanguan nasional. Pembangunan nasional adalah usaha peningkatan kualitas manusia dan masyarakat Indonesia di segala bidang secara berkelanjutan dengan memanfaatkan kemajuan ilmu pengetahuan dan teknologi. Dengan upaya pembangunan nasional tersebut diharapkan akan terwujud kesejahteraan sosial bagi seluruh

14 | Tamliha Harun | Upaya Penanggulangan ..... 
rakyat Indonesia yang merata secara material maupun spiritual.

Undang-Undang Nomor 11 Tahun 2009

tentang Kesejahteraan Sosial, menjelaskan bahwa "Kesejahteraan sosial adalah suatu kondisi terpenuhinya kebutuhan material, spiritual, dan sosial warga negara, agar dapat hidup layak dan mampu mengembangkan diri, sehingga mampu melaksanakan fungsi sosialnya". Kesejahteraan sosial tersebut akan dapat terwujud apabila pemerintah dan rakyatnya saling bersinergi dalam setiap proses pelaksanaan pembangunan di bidang kesejahteraan sosial.

Untuk mewujudkan kesejahteraan sosial tersebut, pemerinah harus bertindak aktif dalam memberikan perhatiaannya kepada warga negara sesuai dengan hak-hak mereka, guna mengembangkan dan meningkatkan kesejahteraan sosialnya sebagaimana yang telah dijamin secara pasti di dalam Undang-Undang Dasar 1945 Pasal 27 ayat (2) bahwa "Tiap-tiap warga negara berhak atas pekerjaan dan penghidupan yang layak bagi kemanusiaan". Untuk memenuhi hak atas pekerjaan dan penghidupan yang layak tersebut, pemerintah bertanggung jawab dan berkewajiban menyediakan lapangan pekerjaan bagi setiap warga negaranya, agar mereka dapat bekerja dan memiliki penghasilan yang tetap, untuk memenuhi kebutuhan hidup yang layak.

Pada kenyataannya negara (pemerintah) hingga saat ini masih belum mampu menciptakan lapangan pekerjaan yang cukup bagi warga negaranya secara menyeluruh dan merata, sehingga angka pengangguran terus meningkat dan jumlah masyarakat/penduduk miskin semakin bertambah. Akibatnya adalah menimbulkan banyak dampak sosial di masyarakat, seperti maraknya tindak kejahatan (perampokan, pencurian, pelacuran), dan menjamurnya gelandangan dan pengemis.

Sebagai gejala sosial, masalah gelandangan dan pengemis sudah lama ada di tengah-tengah masyarakat, terutama di masyarakat perkotaan. Gejala ini terjadi, salah satu penyebabnya adalah akibat arus urbanisasi, dimana masyarakat desa pindah ke kota untuk mencari pekerjaan, dan ternyata di kota mereka tidak mendapat kesempatan pekerjaan karena alasan rendahnya pendidikan dan kurangnya skill yang dimiliki, sehingga terjadilah pengangguran. Untuk memenuhi tuntutan hidup di perkotaan, mereka terpaksa memilih jalan hidup sebagai gelandangan dan pengemis.

Di dalam Undang-Undang Dasar 1945 Pasal 34 dinyatakan bahwa "Fakir miskin dan anak-anak terlantar dipelihara oleh negara". Itu artinya warga negara miskin dan anak-anak terlantar, termasuk gelandangan dan pengemis merupakan tanggung jawab negara atau pemerintah, baik pemerintah pusat maupun pemerintah daerah.

Untuk mengatasi masalah kemiskinan, anak terlantar, gelandangan dan pengemis tersebut sudah banyak program-program yang telah dilaksanakan, baik oleh pemerintah pusat maupun oleh pemerintah daerah, secara langsung maupun tidak langsung. Di samping itu berbagai lembaga masyarakat/swasta juga telah pula diikut-sertakan mambantu pemerintah dalam menanggulangi permasalahan tersebut. Namun pada kenyataannya sampai sekarang masalah fakir miskin, anak terlantar, gelandangan dan pengemis masih merupakan masalah kesejahteraan sosial yang belum terpecahkan secara tuntas, buktinya adalah masih banyak di temukan fakir miskin, anak terlantar, gelandangan dan pengemis di sekeling kita.

Menurut Kementerian Sosial RI, ada istilah PMKS (Penyandang Masalah Kesejahteraan Sisial), yaitu seseorang atau keluarga yang karena suatt hambatan, kesulitan atau gangguan tidak dapat melaksanakan fungsi sosialnya dan karenanya tidak dapat menjalin hubungan yang serasi dan kreatif dengan lingkungannya, sehingga tidak dapat memenuhi kebuthan hidupnya (jasmani, rohani, dan sosial) secara memadai dan wajar. Hambatan kesulitan dan gangguan tersebut dapat berupa kemiskinan, keterlantaran, kecacatan, ketunaan sosial maupun perubahan lingkunan (secara mendadak) yang kurang mendukung dan menguntungkan. Menurut Kementerian Sosial RI, saat ini tercatat ada 26 jenis PMKS. Salah satu dari 26 jenis PMKS tersebut adalah gelandangan dan pengemis (gepeng).

Secara umum, gelandangan adalah orang yang tidak punya tempat tinggal tetap, tidak 
tentu pekerjaannya, berkeliaran, mondar-mandir kesana-sini tidak tentu tujuannya, bertualang. Sedangkan pengemis adalah orang yang dalam memenuhi kebutuhannya (uang atau makanan), dengan cara meminta-minta atau mengharapkan belas kasihan orang lain. Sementara, gelandangan-pengemis (gepeng) merupakan orang yang hidupnya menggelandang, tidak punya rumah/tempat tinggal tetap, berpindahpindah dari satu tempat ke tempat yang lain, dan pekerjaannya sehari-hari adalah mengemis atau meminta-minta (uang/makanan) kepada orang lain.

Martapura adalah ibu kota Kabupaten Banjar, merupakan kota tertua dan terpadat penduduknya di Kalimantan Selatan setelah kota Banjarmasin. Kota ini terkenal dengan sebutan kota intan, karena di buminya banyak ditemukan intan-intan berkualitas tinggi, banyak terdapat pengrajin-pengrajin penggosokan intan, sekaligis pusat transaksi intan dan batu permata lainnya. Di samping itu Kabupaten Banjar (Martapura) terkenal dengan masyarakatnya yang relegius dan memiliki tokoh ulama yang mendunia, sehingga wajar Kota Martapura diberi julukan sebagai Kota Serambi Makkah. Oleh karena itu, Kota Martapura banyak dikunjungi wisatawan yang bertujuan dagang atau transaksi batu permata atau barang lainnya, juga yang bertujuan hanya sekedar wisata relegi mengunjungi situs-situs makam para ulama besar dan terkenal di Kalimantan.

Tidak itu saja, ternyata di Kota Martapura banyak gelandangan dan pengemis, karena keberadaan mereka sangat didukung oleh budaya masyarakatnya yang sangat relegius, berjiwa sosial tinggi, suka menolong/membantu orang miskin, dan suka bersedekah. Hal tersebut sesuai dengan ajaran Islam, bahwa menolong sesama sangat dianjurkan. Di dalam Al Qur'an disebutkan "Wa'ammassa ilafala tanhar", yang intinya kita tidak boleh membentak, menghardik, mengata-ngatai kepada pemintaminta (gelandangan dan pengemis). Oleh karena itu, gelandangan dan pengemis di Kota Martapura (Kecamatan Martapura Kota) Kabupaten Banjar menjadi tumbuh subur.

Seperti kota-kota besar lainnya, masalah gelandangan dan pengemis (gepeng) merupakan masalah pelik yang dihadapi pemerintah daerahnya, termasuk di Kota Martapura Kabupaten Banjar. Untuk menanggulangi masalah gelandangan dan pengemis pemerintah Kabupaten Banjar telah menetapkan Peraturan Daerah Nomor 2 Tahun 2014 Tentang Penanggulangan Gelandangan dan Pengemis

\section{TINJAUAN PUSTAKA}

\section{Batasan Gelandangan dan Pengemis}

Gelandangan dan pengemis (gepeng) merupakan istilah yang umum digunakan dalam pemberitaan media massa bahkan dalam kebijakan pemerintah, yang merujuk pada pengertian sekelompk orang tertentu yang tidak punya tempat tinggal dan kerjanya memintameminta atau mengemis pada orang lain, yang lazim ditemui di kota-kota besar.

Menurut Maghfur Ahmad (2010) kosa kata lain untuk menyebut istilah gelandangan dan pengemis tersebut di masyarakat Indonesia adalah "tuna wisma". Humaidi (2003) menyatakan bahwa gelandangan berasal dari kata gelandang yang berarti selalu mengembara, atau berkelana, dan umumnya hidup sebatang kara.

Anon (1980), berpendapat bahwa gelandangan adalah orang-orang yang hidup dalam keadaan yang tidak sesuai dengan norma kehidupan yang layak dalam masyarakat setempat, serta tidak mempunyai tempat tinggal dan pekerjaan yang tetap di wilayah tertentu dan hidup mengembara ditempat umum. Sedangkan pengemis adalah orang-orang yang mendapatkan penghasilan dengan meminta-minta di muka umum dengan pelbagai cara dan alasan untuk mengharapkan belas kasihan dari orang lain.

Rumusan pengertian gelandangan dan pengemis yang dikemukakan oleh Anon tersebut, ternyata sama dengan rumusan pengertian gelandangan dan pengemis yang terdapat dalam Undang-Undang Nomor 11 Tahun 2009 tentang Kesejahteraan Sosial, dan yang terdapat dalam Peraturan Pemerintah Nomor 31 Tahun 1980 tentang Penanggulangan Gelandangan dan Pengemis.

Berikutnya, menurut Dimas Dwi Irawan (2013) mengatakan bahwa khusus untuk kata pengemis lazim digunakan untuk sebutan bagi 
orang yang membutuhkan uang, makanan, tempat tinggal, atau hal lainnya dari orang yang ditemuinya dengan cara meminta. Berbagai atribut mereka gunakan, seperti pakaian compang camping dan lusuh, topi, gelas pelastik, atau bungkus permen, atau kotak kecil untuk menempatkan uang yang mereka dapatkan dari meminta-minta. Mereka menjadikan mengemis sebagai pekerjaan mereka dengan berbagai macam alasan, seperti kemiskinan dan ketidakberdayaan mereka karena lapangan pekerjaan yang sempit.

Dari beberapa pengertian di atas dapat ditarik suatu kesimpulan bahwa gelandangan itu adalah orang yang tidak mempunyai tempat tinggal dan mata pencaharian tetap, hidup mengembara, serta tidak memiliki kehidupan yang layak dalam masyarakat. Sementara pengemis adalah orang yang pekerjaannya meminta-minta (uang atau makanan) dengan cara mengharapkan belas kasihan orang lain.

\section{Jenis-Jenis Gelandangan dan Pengemis}

Jenis gelandangan ada dua, yaitu gelandangan non psikotik dan gelandangan psikotik. Menurut Perda DIY Nomor 1 Tahun 2014, bahwa gelandangan non psikotik yaitu orang-orang yang hidup dalam keadaan tidak sesuai dengan norma kehidupan yang layak dalam masyarakat setempat, serta tidak mempunyai tempat tinggal dan pekerjaan yang tetap di wilayah tertentu dan hidup mengembara di tempat umum. Sedangkan gelandangan psikotik menurut Irmawan (2009) adalah seseorang yang hidup di jalanan, mengalami gangguan jiwa, dan terlantar. Psikotik merupakan pribadi anti sosial.

Sedangkan pengemis menurut Asmawi (2003) ada dua jenis, yaitu pengemis murni dan pengemis tidak murni. Pengemis murni adalah mereka yang mempunyai tempat tinggal tertentu, yang penghidupan seluruhnya atas dasar meminta-minta pada waktu tertentu. Sedangkan pengemis tidak murni, yaitu mereka yang mempunyai tempat tinggal yang sebagian penghasilannya diperoleh dari meminta-minta pada waktu tertentu.

\section{Karakteristik Gelandangan dan Pengemis}

Menurut Undang-Undang Nomor 11 Tahun 2009 tentang Kesejahteraan Sosial menyebutkan karakteristik gelandangan dan pengemis, sebagai berikut :

1. Karakteristik gelandangan

a. Seseorang (laki-laki/perempuan) usia $18-59$ tahun, tinggal disembarang tempat dan hidup mengembara atau menggelandang di tempat-tempat umum, biasanya di kota-kota besar;

b. Tidak mempunyai tanda pengenal atau identitas diri, berperlaku kehidupan bebas/liar, terlepas dari norma kehidupan masyarakat pada umumnya;

c. Tidak mempunyai pekerjaan tetap, meminta-minta atau mengambil sisa makanan atau barang bekas, dll.

2. Kriteria pengemis

a. Seseorang (laki-laki/perempuan) usia $18-59$ tahun.

b. Meminta-minta di rumah penduduk, persimpangan jalan (lampu lalu lintas), pasa, tempat ibadah, dan tempat umum lainnya.

c. Bertingkah laku untuk mendapatkan belas kasihan, berpura-pura sakit, merintih, dan kadang-kadang mendoakan dengan bacaan-bacaan ayat suci, sumbangan untuk organisasi tertentu,

d. Biasanya mempunyai tempat tinggal tertentu atau tetap, membaur dengan penduduk pada umumnya.

Faktor Penyebab Gelandangan dan Pengemis (gepeng)

Artidjo Alkotsar (1984) menjelaskan bahwa penyebab terjadinya gepeng dapat dibedakan menjadi dua faktor, yaitu faktor internal meliputi sifat-sifat mals, tidak mau bekerja, mental yang tidak kuat, adanya cacat fisik (jiwa). Sedangkan faktor eksternal meliputi faktor sosial, kultural, ekonomi, pendidikan, lingkungan, agama dan letak geografis. 
Selanjutnya, Direktorat Pelayanan dan Rehabilitasi Sosial Tuna Sosial Departemen Sosial (2005) menyebutkan faktor-faktor yang menyebabkan seseorang menjadi gepeng, sebagai berikut :

a. Tingginya tingkat kemiskinan yang menyebabkan seseorang tidak mampu memenuhi kebutuhan dasar minimal dan menjangkau pelayanan umum, sehingga tidak dapat mengembangkan kehidupan pribadi maupun keluarga secara layak.

b. Rendahnya tingkat pendidikan dapat menjadi kendala seseorang untuk memperoleh pekerjaan yang layak.

c. Kurangnya keterampilan kerja menyebabkan seseorang tidak dapat memenuhi tuntutan pasar kerja.

d. Faktor sosial budaya, seperti rendahnya harga diri pada sekelompok orang, sikap pasrah pada nasib, kesenangan hidup bebas dan menggelandang, serta didukung oleh lingkungan sekitar dan pemberi sedekah.

Berdasarkan pendapat tersebut di atas dapat disimpulkan bahwa faktor penyebab utama seseorang menjadi gepeng tidak terlepas dari faktor kemiskinan dan kemalasan, sebab seseorang tidak akan mengemis kalau dia tidak dalam kondisi misikin, atau seseorang tidak mungkin mengemis kalau dia tidak malas bekerja.

\section{METODE PENELITIAN}

Metode penelitian yang digunakan dalam penelitian ini adalah penelitian kepustakaan (library research) dan penelitian lapangan (field research). Sedangkan tipe dan pendekatan yang digunakan dalam penelitian ini adalah pendekatan deskriptif- kualitatif.

Sumber data yang digali dalam penelitian ini adalah data primer dan data sekunder. Data primer diperoleh dari informanyang terkait, yaitu pejabat terkait pada Dinas Sosial Kabupaten Banjar, Satuan Polisi Pamong Praja (Satpol PP), dan beberapa gelandangan dan pengemis di Kecamatan Martapura Kota Kabupaten Banjar. Sedangkan data sekunder diperoleh dari dokumen, catatan, laporan, arsip, dan lain-lain yang berhubungan dengan obyek penelitian.

Teknik pengumpulan data yang digunakan dalam penelitian ini adalah teknik wawancara, teknik observasi dan teknik dokumentasi. Untuk melakukan kajian atau analisis terhadap data peneltian yang diperoleh, digunakan analisis data kualitatif, yaitu dengan cara melakukan pengolahan dan klasifikasi data yang ada, kemudian dilakukan analisis atau kajian secara rasional dan obyektif dengan cara merujuk pada Peraturan Daerah Kabupaten Banjar Nomor 2 Tahun 2014 Tentang Penangulangan Gelandangan dan Pengemis.

\section{HASIL DAN PEMBAHASAN}

Berdasarkan data penelitian yang diperoleh dan analisis data yang dilakukan, maka hasil penelitian tentang upaya penanggulangan gelandangan dan pengemis di Kecamatan Martapura Kota Kabupaten Banjar, dapat dideskripsikan sebagai berikut:

\section{Upaya Pencegahan (Preventif)}

Menurut Perda Kabupaten Banjar Nomor 2 Tahun 2014 Tentang Penanggulangan Gelandangan dan Pengemis, ditegaskan bahwa pencegahan adalah upaya yang dilakukan oleh pemerintah dan/atau masyarakat untuk mencegah berkembang dan meluasnya jumlah penyebaran dan kompleksitas permasalahan penyebab adanya anak di jalanan, gelandangan dan pengemis. Usaha pencegahan yang dilakukan, antara lain adalah pendataan, pemantauan, pengendalian, dan pengawasan, sosialisasi, dan penyuluhan.

Berdasarkan hasil wawancara dan pengamatan yang dilakukan, diperoleh informasi bahwa kegiatan pencegahan gepeng di Kecamatan Martapura Kota sudah dilakukan oleh aparat Dinas Sosial, yaitu dengan melakukan kegiatan pendataan, sosialisasi, dan penyuluhan. Kegiatan pendataan dilakukan dengan tujuan untuk mengetahui secara akurat jumlah dan sebaran tempat gepeng biasa beroperasi. Sosialisasi ditujukan kepada tokoh masyarakat, agar mereka ikut terlibat dalam upaya pencegahan terjadinya gepeng. Sedangkan 
penyuluhan ditujukan kepada masyarakat, terutama yang rawan menjadi gepeng agar mereka mengetahui dan memahami bahwa gepeng adalah perbuatan yang dilarang oleh pemerintah (perda). Disamping itu juga dilakukan pemasangan spanduk di titik-titik tertentu yang isinya larangan terhadap kegiatan pergelandangan dan pengemisan di tempattempat umum.

Kegiatan pencegahan gepeng juga dilakukan oleh aparat Satuan Polisi Pamong Praja (Satpol PP), yaitu dengan melakukan kegiatan pemantauan, pengendalian, dan pengawasan dengan melakukan patroli secara rutin ditempat-tempat yang rawan operasi para gepeng. Namun demikian, upaya preventif yang dilakukan oleh aparat Dinas Sosial dan Satpol PP tersebut hasilnya belum maksimal, terbukti masih banyak para gepeng berkeliaran menjalankan operasinya di tempat-tempat umum yang strategis.

\section{Upaya Penanggulangan (Represif)}

Menurut Perda Kabupaten Banjar Nomor 2 Tahun 2014 Tentang Penanggulangan Gepeng, dijelaskan bahwa penanggulangan adalah usaha untuk mengurangi atau membebaskan tempattempat umum dari gelandangan dan pengemis yang ditujukan baik kepada seseorang maupun kelompok. Usaha penanggulangan meliputi antara lain razia, perlindungan, pengendalian sewaktu-waktu, penampungan sementara, pendekatan awal, pengungkapan dan pemecahan masalah (assesment), pendampingan sosial, dan rujukan berdasarkan seleksi.

Dari hasil wawancara dan pengamatan yang dilakukan, diperoleh informasi bahwa kegiatan penanggulangan gepeng di Kecamatan Martapura Kota, terutama kegiatan razia sudah sering dilakukan. Pada umumnya sebelum razia gepeng dilakukan Tim Penanggulangan (Dinas Sosial, Satpol PP, Polres, Polsek, Aparat Kecamatan, Trantib, dan Koramil) melakukan rapat koordinasi. Ketika turun ke lapangan melakukan kegiatan penanggulangan (razia) masing-masing anggota Tim Gabungan tersebut melaksanakan tugasnya sesuai hasil kesepakatan rapat. Biasanya tempat-tempat yang menjadi sasaran razia yaitu sepanjang jalan A. Yani,
Pasar CBS, Taman Alun-Alun, Masjid Agung Al Qaromah, PPS Sekumpul, Jl. Pendidikan, Astambul, Kelampaian, dan pusat keramaian lainnya.

Tindak lanjut dari kegiatan razia adalah penangkapan gepeng sedang melakukan aksinya di tempat-tempat umum yang dirazia. Gepeng yang terjaring dalam razia tersebut dibawa dan dikumpulkan di tempat penampungan sementara milik Dinas Sosial. Di tempat penampung sementara dilakukan pendataan/identifikasi terhadap gepeng tersebut. Selanjutnya diberikan pembinaan secara sosial dan mental, serta dilakukan sock terapy.

Setelah selesai dilakukan pembinaan, para gepeng tersebut dikembalikan/dipulangkan dengan syarat/perjanjian. Bagi gepeng yang berasal dari luar kota/daerah, mereka dipulangkan ke daerah asal dengan didampingi oleh aparat/petugas dari Dinas Sosial. Upaya penanggulangan yang dilakukan oleh Dinas Sosial hanya sebatas pada tahap pembinaan di tempat penampungan sementara, tidak ada tindakan lanjutan atau rujukan ke tempat rehabilitasi sosial/panti sosial, karena pemerintah Kabupaten Banjar tidak memiliki tempat tersebut, yang ada hanya rumah singgah milik pemerintah provinsi bagi gepeng yang akan dipulangkan ke luar kota/daerah.

Berdasarkan hasil wawancara dan pengamatan tersebut dapat ditarik suatu kesimpulan bahwa upaya penanggulangan gepeng yang dilakukan oleh Tim Gabungan tersebut belum maksimal sebagaimana yang digariskan oleh perda, karena keterbatasan prasarana yang dimiliki pemkab, yaitu terbatasnya tempat penampungan sementara yang ada dan tidak adanya tempat rehabilitasi/ panti sosial, sehingga pembinaan gepeng yang sudah terjaring dalam razia tersebut tidak bisa maksimal dilakukan, dan sering terjadi para gepeng yang terjaring dan sudah diberikan pembinaan tersebut kembali menggelandang dan mengemis kembali.

\section{Upaya Rehabilitasi (Rehabilitatif)}

Menurut Perda Nomor 2 Tahun 2014 Tentang Penanggulangan Gelandangan dan Pengemis, dijelaskan bahwa rehabilitasi sosial 
merupakan proses refungsionalisasi dalam tata kehidupan bermasyarakat dan peningkatan taraf kesejahteraan sosial terhadap gepeng yang dilakukan melalui sistem panti atau luar panti. Upaya yang dilakukan dalam rehabilitasi sosial antara lain meliputi kegiatan seleksi, bimbingan mental spiritual, bimbingan fisik, bimbingan sosial, bimbingan dan pelatihan keterampilan, membantu stimulasi peralatan kerja, dan penempatan/penyaluran.

Dari hasil wawancara yang dilakukan, diperoleh informasi bahwa Pemkab Banjar dalam upaya penanggulangan gepeng hanya sebatas kegiatan preventif dan represif saja, itu pun belum maksimal. Pemkab Banjar tidak bisa melakukan kegiatan rehabilitasi sosial, karena tidak memiliki sarana dan prasarana yang menunjang, yaitu tempat rehabilitasi sosial/panti sosial untuk menampung para gepeng yang sudah mendapatkan pembinaan di tempat penampungan sementara. Bahkan Pemprov Kalsel pun juga tidak memiliki rempat rehabilitasi sosial/panti sosial. Pemprov Kalsel hanya memiliki rumah singgah untuk gepeng yang akan dipulangkan ke luar kota atau daerah.

Tempat rehabilitasi sosial/panti sosial merupakan tempat yang sangat penting untuk pembinaan/bimbingan lanjutan bagi gepeng yang sudah mendapat pembinaan di tempat penampungan sementara. Di tempat ini mindset/sikap mental gepeng digodok dan dirubah, serta diberikan pembekalan keterampilan dan bantuan peralatan kerja untuk pemberdayaan diri gepeng. Dengan cara itu diharapakan tingkat kesejahteraan mereka terangkat dan refungsionalisasi kehidupannya di masyarakat pulih kembali, sehingga kegiatan menggelandang dan mengemis itu mereka tinggalkan.

\section{Sanksi Pidana Terhadap Gepeng}

Perda Kabupaten Banjar Nomor 2 Tahun 2014 tentang Gelandangan dan Pengemis mengatur sanksi pidana bagi gepeng, yaitu sanksi berupa pembinaan dengan cara introgasi, identifikasi, serta membuat perjanjian yang mengikat agar tidak melakukan kegiatan gepeng di tempat umum dan/atau jalanan yang disaksikan oleh aparat dan/atau petugas yang berwenang, dan perjanjian dimaksud dapat dijadikan sebagai alat bukti di pengadilan; Bagi gepeng yang telah membuat perjanjian tersebut, kemudian masih melakukan aktivitas gepeng kembali, maka akan dapat dikenakan pidana kurungan paling lama 3 (tiga) bulan kurungan dan/atau denda paling banyak Rp 5.000.000,00 (Lima Juta Rupiah).

Namun dalam pelaksanaannya di lapangan ancaman sanksi pidana kurungan tersebut belum pernah terjadi atau belum pernah sampai ke pengadilan. Paling sanksi ringan yang pernah diterapkan, seperti sanksi berupa pembinaan dengan cara introgasi, identifikasi, membuat perjanjian yang mengikat agar mereka tidak lagi melakukan kegiatan gepeng di tempattempat umum. Kalaupun dikenakan sanksi denda, paling dendanya hanya sekitar Rp 200.000,- (Dua ratus Ribu Rupiah). Oleh karena penerapan sanksi pidana yang dikenakan kepada gepeng terlalu ringan, dan tidak ada efek jeranya, maka praktik gelandangan dan pengemis di Kecamatan Martapura Kota Kabupaten Banjar tetap marak terjadi.

\section{KESIMPULAN}

Berdasarkan pada hasil penelitian dan pembahasan tersebut di atas, maka dapat disimpulkan sebagai berikut :

a. Penaggulangan gelandangan dan pengemis di Kabupaten Banjar (khususnya di Kecamatan Martapura Kota) sudah dilakukan melalui upaya pencegahan (preventif), upaya penanggulangan (represif), dan upaya rehabilitasi (rehabilitatif) berdasarkan Peraturan Daerah Nomor 2 Tahun 2014 Tentang Penanggulangan Gelandangan dan Pengemis.

b. Upaya-upaya penanggulangan gelandangan dan pengemis yang dilakukan Pemerintah Kabupaten Banjar tersebut masih belum maksimal, apabila dirujuk pada Perda yang mamayunginya, terutama upaya rehabilitasi belum terlaksana dengan baik.

c. Belum maksimalnya upaya-upaya penaggulangan gelandangan dan pengemis tersebut, disebabkan beberapa 
kendala, antara lain : kurangnya jumlah aparat, baik pada Dinas Sosial maupun Satpol PP, kurangnya alokasi anggaran untuk penanggulangan gepeng, dan belum tersedianya sarana dan prasarana pembinaan gepeng sesuai kebutuhan.

d. Sanksi pidana maupun sanksi non pidana sesuai Perda, belum bisa diterapkan secara tegas dan konsisten kepada gepeng yang telah melakukan pelanggaran, akibatnya sanksi-sanksi yang dikenakan kepada gepeng tidak menimbulkan efek jera.

\section{REFERENSI}

Ahmadi, Ruslan. 2016. Metodologi Penelitian Kualitatif. Yogyakarta: Cet. III, .Ar-Ruzz Media.

Alkotsar, Artidjo. 1984. Advokasi anak Jalanan, Rajawali. Jakarta (dalam https://erepo.unud.ac.id 01/05/2017).

Asmawi, M. 2003. Persoalan Kemiskinan dalan Orientasi Kebijaksanaan Pembangunan. Bandung: Majalah Ilmu PDP Unpad Prakarsa.

Dit. Pelayanan dan Rehabilitasi Sosial Tuna Sosial Depsos RI, 2005. Standar Pelayanan Minimal Pelayanan dan rehabilitasi Sosial Gelandangan dan Pengemis. (dalam http://erepo.unid.ac.id 01/05/2017)

Irawan, Dimas Dwi. 2013. Pengemis Undercover Rahasia Seputar Kehidupan Pengemis. Jakarta: Titik Media Publisher.

Irmawan, dkk. 2009. Penangan Keterlantaran Kelandangan Psikotik di Luar Panti. Jakarta: Citra Media.

Maghfir, Ahmad. 2010. Strategi Kelangsungan Hidup Gelandangan dan Pengemis. Jurnal Penelitian STAIN Pekalongan, Vol 7 No. 2 (dalam http://www.google.co.id. Gepeng/2017/04/25).
Peraturan Daerah Kabupaten Banjar Nomor 2 Tahun 2014 Tentang Gelandangan dan Pengemis.

Peraturan Pemerintah Nomor 31 Tahun 1980 tentang Penangulangan Gelandangan dan Pengemis (https://www.google.co.id. Gepeng/2017/05/01).

Sekretariat Jenderal MPR-RI. 2017. UUD NEGARA RI 1945. 